DOI https://doi.org/10.30525/978-9934-26-004-9-106

\title{
ЕТНІЧНІ МОТИВИ У СУЧАСНИХ ТЕКСТИЛЬНИХ ФАКТУРНИХ РІШЕННЯХ
}

Колосніченко М. В.

доктор технічних наук, професор, декан факультету дизайну

Остапенко Н. В.

доктор технічних наук, професор, завідувач кафедри ергономіки і проектування одягу

Михайлюк О. Ю. аспірант кафедри ергономіки і проектування одягу

Луцкер Т. В.

кандидат технічних наук, доцент кафедри ергономіки і проектування одягу

Бризгунова М. С.

студент II курсу кафедри художнього моделювання костюма факультету дизайну

Київського начіонального університету технологій та дизайну м. Київ, Украӥна

Актуальною тенденцією сучасної дизайн-практики є звернення до культурно-історичних витоків. Зближення i взаємопроникнення різноманітних етнокультурних традицій у моді сприяє виникненню численної кількості нових образно-стильових та кольоро-фактурних рішень виробів.

Метою даної роботи є огляд шляхів використання етномистецьких традицій у дизайні сучасних текстильних фактурних рішень.

Актуальність дослідження полягає у вивченні особливостей використання етнічних мотивів як джерела натхнення у проектній творчості, а також у необхідності розкриття художньо-естетичних особливостей синтезу історико-культурного та мистецтвознавчого підходів до дизайну.

Загалом, у більшості наукових розвідок автори порушують проблематику етно- та національних традицій в окремих сферах дизайну. Автор [1] в роботі «Вияв етнічної культури в дизайні сучасних готельних 
комплексів України» застосовує поняття «етностиль» окреслюючи цим терміном стильовий напрям, який створюють професійні художники, дизайнери, архітектори, активно використовуючи національний колорит певного народу. Науковці $[2,3,4,5]$ у своїх дослідженнях подають загальну різносторонню характеристику етностилю. Загальних питань щодо сучасних пошуків «великого стилю» в ділянці українського декоративного мистецтва XX ст. торкаються Т. Кара-Васильєва та 3. Чегусова в широкому огляді його видів та форм [6].

Етнодизайн відповідає змістовим та естетичним характеристикам конкретної культури 3 урахуванням національного колориту, характерного для того чи іншого народу. Цей напрям створює сучасні форми матеріального середовища з елементами культури певного етносу.

Слід зауважити, що існує негативна оцінка етностилю та етнодизайну. Автор [7] зазначає, що етностиль оперує лише окремими мотивами певного народного стилю, а це призводить до нівелювання духовного змісту елементів етнічної культури та робить його виключно декоративним, притаманним країнам «третього світу», інструментом «промоутерів глобалізації» та «руйнівником етнокультури». Оскільки достатнього теоретичного обгрунтування поняття «етностилю» немає і в словниках визначення цього явища відсутне, автор [8] пропонує використовувати термін «етнічні мотиви».

Відомо також [9], що використання етно-культурних традицій не $\epsilon$ новим підходом у дизайні виробів. Стиль «фольк» виник у другій половини XX ст. на тлі існування різноманітних субкультур та модних напрямів і вже тривалий час існує самостійно та в комбінуванні з іншими стилями.

Серед ознак, за якими визначають належність виробів до певного етнічного стилю $\epsilon$ форма, фактура та колорит використовуваних матеріалів, особливості композиційно-пластичних рішень, характер оздоблення та декору, в тому числі мотиви та техніки виконання орнаменту, фактурного рішення тощо.

Творча інтерпретація етнотрадицій в мистецтві та дизайні $\epsilon$ результатом емоцій, інтуїції, фантазії і особистого світосприйняття дизайнера, але, разом 3 тим, вимагає обгрунтування, уточнення, перевірки логікою, знанням та накопиченим практичним досвідом.

Відомо [10], що важливу роль у створенні пластичної форми виробів відіграє характер структури поверхні, тобто фактура матеріалу (від лат. factura - обробка, будова), його лицьова поверхня, одержана в результаті певної технологічної обробки. Фактурне оздоблення відкриває широкі можливості збагачення композиції та підвищення художньої виразності 
виробу. У зв'язку з цим, його широко застосовують в різних напрямах мистецтва та об'єктах дизайну.

Текстильні фактурні рішення використовують як інструмент посилення художньої виразності різних об'єктів - виробів домашнього вжитку та оздоблення інтер'єру, одягу, аксесуарів, взуття тощо. В образотворчому мистецтві фактурні рішення $є$ основою та засобом відображення у творах текстильного живопису, зокрема портретного, пейзажного жанру та текстильної скульптури, а також широко розповсюджені при створенні інсталяцій, енвайронменту тощо.

Фактурні рішення текстильних виробів у етностилі отримують шляхом застосування різновидів технік вишивки, аплікації, валяння, штучного зістарювання, художнього розпису; перфорації; плетіння; плісирування; гофрування; ткацтва; драпірування; фурнітури та різноманітних декоративних елементів тощо.

Трансформація традиційних народних декоративних технік оздоблення текстилю для створення сучасних фактурних рішень дає можливість знайти нову образну мову в художньому оформленні виробів через пошук нових форм та концепцій.

Разом 3 тим, глобалізація і, як наслідок, уніфікація естетичних стандартів та масове застосування традиційних етномистецьких компонентів часто призводить до їх надмірного спрощення, примітивізації і нерідко містить ознаки кічу. Художні засоби створення естетично досконалих об'єктів етнодизайну грунтуються на дослідженні сакрального та семантичного змісту елементів культури певного народу, синтезуванні набутого досвіду, розумінні форми та образу.

Отже, використання етнічних мотивів у сучасних текстильних фактурних рішеннях не $є$ наслідуванням або копіюванням, а базується на дослідженні і глибинному розумінні культурних традицій, художньоестетичних канонів та проектних характеристик, створюючи при цьому новий візуальний образ.

\section{Література:}

1. Рудик Д. С. Вияв етнічної культури в дизайні сучасних готельних комплексів України. Українська культура: минуле, сучасне, шляхи розвитку: Зб. наук. праць: наук. зап. Рівненського державного гуманітарного університету. Рівне: РДГУ, 2011. Вип. 17, том 1, с. 124-129.

2. Квасниця Р. Етнічний напрямок у дизайні демонстраційних просторів для модних інновацій. ВІСНИК Львівської національної академії мистецтв, 2018. Вип. 37, с. 135-150. 
3. Крилатова О. С. Вектори розвитку етностилю в сучасному дизайні громадських інтер'єрів України. ВІСНИК Львівської національної академії мистецтв, 2013. Вип. 24, с. 27-38.

4. Чупріна Н.В., Гайова І.Л., Паламар К. І. Етнодизайн та його реалізація в сучасному проектуванні костюма та індустрії моди. [Електронний ресурс] Технології та дизайн. 2016. № 3 (20). Режим доступу: http://nbuv.gov.ua/UJRN/td_2016_3_13.

5. Богайчук Л.Р. Етно-стиль розпису тканини в процесі підготовки майбутніх учителів образотворчого мистецтва. [Електронний ресурс] Науковий вісник Південноукраїнського національного педагогічного університету ім. К. Д. Ушинського. Педагогічні науки. 2016. № 3, с. 7-11. Режим доступу: http://nbuv.gov.ua/UJRN/Nvpupupp_2016_3_3.

6. Кара-Васильєва Т., Чегусова 3. Декоративне мистецтво України ХХ ст. У пошуках «великого стилю» Київ: Либідь, 2005. 275 с.

7. Афанасьєв Ю. Л. Етностиль у контексті етнокультурної та глобалізаційної парадигми. Мистецтвознавчі записки. 2011. Вип. 19, c. $197-202$.

8. Громнюк А. І. Етнічні мотиви в архітектурі сучасних інтер'єрів підприємств харчування. Дисертація на здобуття наукового ступеня кандидата архітектури. Спеціальність: 18.00.01 - теорія архітектури, реставрація пам'яток архітектури. Національний університет «Львівська політехніка». Львів, 2016.

9. Кротова Т. Ф. Етно-мотиви і класичні форми в костюмі: свобода перевтілень і межі стилю. [Електронний ресурс]. Київський університет імені Бориса Грінченка. Київ. Режим доступу: http://elibrary. kubg. edu. ua/3961/2/T_Krotova_MK_Text.Pdf.

10. Супрун Н. П., Колосніченко М. В., Суворова О. К. Художне оформлення текстильних матеріалів. Навч. посібн. Київ: КНУТД, 2012. $135 \mathrm{c}$. 